\title{
CONSTITUTIONAL LIMITATIONS ON THE FORCIBLE EXTRACTION OF BODY FLUIDS BY LAW ENFORCEMENT OFFICERS
}

$\mathrm{M}^{\mathrm{s}}$

ODERN crime detection techniques made possible by recent technological advances have, in many instances, become standard procedure with law enforcement agencies. ${ }^{1}$ While many of these methods are, as yet, of dubious scientific accuracy, ${ }^{2}$ the reliability of body fluid analyses has been established beyond cavil, ${ }^{3}$ and, on a technical level, no objection can effectively be interposed to their employment for evidentiary purposes. Where the body fluids have been forcibly extracted, however, there arise three possible constitutional objections: ${ }^{4}$ First, it may be

${ }^{2}$ The more important cases are collected in Note, Admissibility of Evidence $O b_{-}$ tained by Scientific Devices and Analyses, 5 U. FLA. L. REv. 5 (I952). The use of photographs, motion pictures, ballistics tests, wire and tape recorders, $\mathrm{X}$-rays, typewriting and handwriting analyses, wire-tapping, and fingerprinting is too well established to merit extensive discussion herein, however.

"The history of the development of truth serums dates back to 1922 when scopolamine was first used in this connection. The principal objection to the use of such drugs for the purpose of securing a confession is the strong possibility that it may be false. "It is subject to being mingled with fancy. It is subject to being molded by the suggestions of the interrogator. In the hands of incompetent or unethical interrogators, a suspect can make a wide variety of unreliable statements." Despres, Legal Aspects of Drug-Induced Statements, 14 U. CHI. L. REV. 601, 606 (1947).

The hypnotic trance can produce similar difficulties. Illusions and hallucinations are always possible, and the hypnotist can manipulate his subject almost at will. See Note, 5 U. FLA. L. REv. 5, 10 (1952) and cases therein cited.

Results obtained from lie-detector and drunkometer tests have likewise been held inadmissible, the former not having been technically perfected to a sufficient degree of accuracy, INBAU, SELF-INCRIMINATION, 66-68 (1950), and the latter because the accuracy of its results is directly dependent upon the skill of its operator. Harger, "Debunking" the Drunkometer, 40 J. CRIM. L., C. \& P.S. 497 (1949).

'Blood and urine tests are generally accepted today for their accuracy. Despres, Legal Aspects of Drug-Induced Statements, 14 U. CHI. L. REv. 601, 609 (1947).

See Inbau, Self-InCRimination 72-82 (1950) for the cases in which the results of such tests have been admitted. As a general standard, it is agreed that the presence in the blood of 150 milligrams of alcohol per roo cubic centimeters of blood will create a presumption of intoxication. Ladd and Gibson, Legal-Medical Aspects of Blood Tests to Determine Intoxication, 29 VA. L. REv. 749, 752 (1943); Muelberger, Medico-Legal Aspects of Chemical Tests of Alcoholic Intoxication, 39 J. CrIM. L., C. \& P.S. 411,412 (1948).

'These objections can be raised only if the extraction is achieved by force or compulsion, for, if the accused submits voluntarily, the doctrine of waiver will preclude the raising of any constitutional objection to the use of such evidence, unless the subject 
asserted that the accused's privilege against self-incrimination has been violated; second, that the conduct of police officers constituted an unreasonable search and seizure; and third, that conduct of police officers constituted acts of a character so violent or brutal as to amount to a denial of due process of law. ${ }^{5}$ How valid are they?

\section{Decisions in the Féderal Courts}

The privilege against self-incrimination was narrowly defined in Holt v. United States, ${ }^{,}$where Mr. Justice Holmes announced for the Court that ${ }^{7}$

... the prohibition of compelling a man in a criminal court to be a witness against himself is a prohibition of the use of physical or moral compulsion to extort communications from him, not an exclusion of his body as evidence when it may be material. ...

As authoritatively restated by Professor Wigmore, the scope of the fifth amendment privilege against self-incrimination was limited to testimonial evidence. ${ }^{8}$ Thus, it would seem that the accused who con-

matter is jurisdictional. CoOley, Constitutional Limitations 667 (8th ed. 1927). With regard to the fifth amendment privilege agamst self-incrimination, in particular, the Supreme Court has held that a witness must expressly assert and claim his constitutional immunity, or he will be deemed to have waived it. Rogers v. United States, 340 U.S. 367,370 (I95I); United States v. Monia, 3 I 7 U.S. 424, 427 (1943).

See generally, Silving, Testing of the Unconscious in Criminal Cases, 69 HaRv. L. REv. 683 (1956).

${ }^{5}$ These three constitutional objects are not the only ones which have been raised. For example, it has been suggested that the Supreme Court in Rochin v. California, 342 U.S. 165 (1952) rested its decision on what it considered to be an invasion of the person. State v. Berg, 76 Ariz. 96, 259 P.2d 261 (1953). That this interpretation of the Rochin decision, however, is without foundation is pointed out in Note, 4I CALIF. L. REv. 728 (1953).

- 218 U.S. 245 (1910).

${ }_{21} 8$ U.S. $245,252-253$ (1910). The Holt case marks the initial adoption by the Supreme Court of the view that the fifth amendment privilege extends only to testimonial evidence. In that case, defendant was charged with murdering another by bludgeoning him with au iron bar, was convicted and sentenced to life imprisonment. One of the errors alleged on appeal was that the accused had been compelled to try on a blouse which the authorities claimed belonged to him. A witness, called by the prosecution, testified that he had seen the accused put on the blouse and that it fitted him. The Court held that the defendant had not been compelled to testify against himself by trying on the blouse, thus establishing the limits of the privilege.

8 WIGMORE, EVIDENCE $\S 2265$ (3d ed. 1940) and cases cited therein. It has been held specifically that a urine specimen does not fall within the scope of the privilege. United States v. Nesmith, 12 I F. Supp. 758, 762 (D.D.C. 1954). Many jurisdictions, however, do not draw any distinction between testimonial evidence and real evidence 
tends that the admission into evidence of body fluids forcibly extracted from him violates his privilege against self-incrimination will be flaying a very dead horse. ${ }^{\circ}$.

In United States $v$. Willis, ${ }^{10}$ a federal district court held that forcible evacuation of the stomach contents of the accused violated the fourth amendment prohibition against unreasonable searches and seizures and that evidence obtained thereby might not be admitted. ${ }^{11}$ This protection,

for the purpose of defining the scope of the privilege created by the particular state constitutional or statutory provision.

The line between testimonial and real evidence is not the only distinction which has been drawn although this is generally regarded as the orthdox approach. It has been suggested that the privilege extend to any evidence secured by compulsion. Some attempts have even been made to differentiate between "forced passivity" and "forced activity," but the application of these so-called tests in actual cases reveals that they are, at best, only labels. See Note, 44 KY. L.J. 353 (1956). See generally, Comment, To What Extent Does the Privilege A gainst Self-Incrimination Protect an Accused from Physical Disclosures, I VAND. L. Rev. 243 (1948). Cf. Gouled v. United States, 255 U.S. 298 (1921).

- There has been, however, a vigorous attack on the statement of Holmes in the Holt case, despite its apparent widespread acceptance as the general rule in this area. Justices Black and Douglas would extend the privilege of the accused so as to encompass "words taken from his lips, capsules taken from his stomach, blood taken from his veins. ..." Rochin v. California, 342 U.S. 165,179 (1952) (concurring opimion). See also Breithaupt v. Abram, 352 U.S. 432, 443 (1957) (dissenting opinion). This thesis, however, runs afoul of the decisions of the Court in Twining v. New Jersey, 2 II U.S. 78 (1908) and, subsequently, in Adannson v. California, 332 U.S. 46 (1947) to the effect that the due process clause of the fourteenth ainendment does not incorporate, as a limitation on state governments, the self-incrimination clause of the fifth amendment.

${ }^{10} 85$ F. Supp. 745 (S.D. Cal. 1949).

${ }^{11}$ The Court first held that probable cause existed for the arrest of the defendant and that the search, incidental to the arrest, which revealed certain money and a match folder "was reasonable within the meaning of the Fourth Amendment." 85 F. Supp. 745, 747 (S.D. Cal. 1949). This holding is in accord with a line of Supreme Court decisions permitting searches and seizures when incidental to arrest. See Weeks v. United States, 232 U.S. 383,392 (1914); Agnello v. United States, 269 U.S. 20 (1925); Marron v. United States, 275 U.S. 192 (1927). Cf. Harris v. United States, 33 I U.S. 145 (1947) and United States v. Rabinowitz, 339 U.S. 56 (1950).

The district court in the Willis case then went on to hold that the evidence obtained by meaus of the stomach pump was the fruit of an unreasonable search within the purview of the fourth amendment. 85 F. Supp. 745,749 (S.D. Cal. 1949). This conclusion was reached only after extensive analysis of Harris v. United States, supra. The court also relied extensively on the case of In re Guzzardi, 84 F. Supp. 294 (N.D. Tex. 1949), since that case similarly involved the use of a stomach pump to obtain inorphine which the accused had swallowed. The court in that case rested its decision on unreasonable search and seizure grounds, pointing to the words of the fourth amendment which insures to the people the right to be secure in their persons, houses, papers, and effects. The court said, "if the stomach pump can be justified, then the opening of 
however, has been limited to defendants in federal courts, since the United States Supreme Court in Wolf v. Colorado, ${ }^{12}$ while ruling that the due process clause of the fourteenth amendment extends the fourth amendment prohibition against unreasonable searches and seizures to the states, ${ }^{13}$ concluded that the federal exclusionary rule did not prohibit the use of such evidence in state courts. ${ }^{14}$ Hence, in the absence of a state exclusionary rule, ${ }^{15}$ an objection to the forcible extraction of body fluids on the ground that it constitutes an unreasonable search and seizure will avail the defendant but little.

The Supreme Court revitalized this "virtually meaningless protection from unreasonable searches and seizures by state officers" in

one's person by the surgeon's knife can be justified. We should then have returned to trial by ordeal which has long since been abolished by right-thinking, liberty-loving people." (The logical connection between surgical operation and trial by ordeal is not clear.)

The temper of the opinions in the Willis and Guzeardi cases, as well as the dissent in the Harris case would seen to forecast the rationale adopted in the Rochin case, i.c., that the Constitution will not countenance conduct by law enforcement officers which "shocks the conscience." For a discussion of the Willis case, see Bachelder, Use of Stomach Pump as Unreasonable Search and Seizure, 41 J. CRIM. L., C. \& P.S. 189 (1950).

12338 U.S. 25 (1949).

${ }^{28}$ The federal exclusionary rule was pronulgated in Weeks v. United States, 232 U.S. 383 (1914), and has since been adopted in about one-half of the states. As such, it is limited in its application only to that evidence unlawfully seized by state officers as is the federal rule limited to actions of federal officers. Lustig v. United States, 338 U.S. 74 ( 1949 ); Byars v. United States, 273 U.S. 28 ( 1927 ). The federal exclusionary rule "was not derived from the explicit requirements of the fourth amendment; it was not based on legislation expressing congressional policy in the enforcement of the Constitution. The decision was a matter of judicial implication." Wolf v. Colorado, 338 U.S. 25, 28 (1949).

1" Mr. Justice Murphy, in dissent, contended that the federal exclusionary rule constituted the only effective means of insuring to all persons the guarantees of the fourth amendment and, therefore, the majority was conferring upon the citizens of the states a virtually meaningless protection from unreasonable searches and seizures by state officers. 338 U.S. 25, 43-44 (1949). For an analysis of the Wolf case and the nnsettled problems still remaining, see Comment, Due Process and the Admissibility of Evidence, 64 HARV. L. REv. I 304 (1951).

${ }^{25}$ At the time the Wolf case was decided, forty-seven states had passed on the exclusionary rule question, sixteen states accepting and thirty-one rejecting it. Mr. Justice Frankfurter appended the majority opinion in Wolf with ten tables of cases indicating this divergence. See Wolf v. Colorado, 338 U.S. 25, 33-39 (r949). Since the Wolf decision, however, California, Delaware, North Carolina, Oregon, and Texas have been added to those states adopting the rule. In addition, it also prevails in the District of Columbia, Alaska and Hawaii. For the latest compilation see 50 A.L.R.2d 53 I (1956). 
Rochin v. California, ${ }^{16}$ the famous stomach pump case, ${ }^{17}$ where it reversed a conviction on the ground that the due process clause of the fourteenth amendment prohibits that type of conduct which shocks the conscience by impinging upon certain decencies of civilized behavior. ${ }^{18}$ In applying this test to the facts of the case, Mr. Justice Frankfurter described the conduct of the officers as constituting "methods too close to the rack and the screw to permit of constitutional differentiation."19 Despite the fact that the accused could have instituted an action for battery against the officers involved, a remedy which apparently prompted the majority in the Wolf case not to extend the exclusionary rule to the states, ${ }^{20}$ the Court felt constrained to rule the evidence in question inadmissible in order to check unconscionable abuses by law enforcement officers.

A limitation was imposed upon the Rochin test by Irvine v. California, ${ }^{21}$ where the Supreme Court indicated that some degree of violent

16342 U.S. 165 (1952).

${ }^{17}$ There, capsules of morphine were forcibly extracted from the suspect's stomach by means of an emetic following an unlawful entry into the suspect's home by state police officers.

${ }^{18}$ The Urited States Supreme Court has long applied due process limitations to state criminal proceedings to prevent an unjust result. For example, the Court has repeatedly reversed convictions obtained by means of coerced confessions, the leading case being Brown v. Mississippi, 297 U.S. 278 (1936). See also, Lisenba v. California, 314 U.S. 219,236 (I94I); Ward v. Texas, 3 I6 U.S. 547 (1942); Asheraft v. Tennessee, 322 U.S. I43 (1944); Malinski v. New York, 324 U.S. 401,.404 (1945); Watts v. Indiana, 338 U.S. 49 (1949); Stroble v. California, 343 U.S. I81, 190 (1952); Leyra v. Denno, 347 U.S. 556 (I954). Cf. Stein v. New York, 346 U.S. $156(1953)$.

${ }^{10} 342$ U.S. 165,172 (1952).

80 "Tndeed, the exclusion of evidence is a remedy which directly serves only to protect those upon whose person or premises something incriminating has been found. We cannot, therefore, regard it as a departure from basic standards to remand such persons, together with those who emerge scatheless from a search, to the remedies of private action and such protection as the internal discipline of the police, under the eyes of an alert public opinion, may afford. Granting that in practice the exclusion of evidence may be an effective way of deterring unreasonable searches, it is not for this Court to condemn as falling below the minimal standards assured by the Due Process Clause a State's reliance upon other methods which, if consistently enforced, would be equally effective." 338 U.S. 25, 30-31 (1949).

${ }^{21} 347$ U.S. I28 (1954). There law enforcement officers planted a microphone in the bedroom of a suspected hookmaker through which they were able to obtain a record of certain incrininating conversations. In disallowing the evidence thus obtained, the Court rested its decision upon search and seizure principles rather than upon due process. Mr. Justice Jackson pointed out that "[H] owever obnoxious are the facts in the case before us, they do not involve coercion, violence or brutality to the person, but rather a trespass to property, plus eavesdropping." 347 U.S. 128, 133 (I954). 
or brutal conduct must be present before that doctrine may be invoked. This theory was elaborated recently in Breithaupt v. Abram, ${ }^{22}$ where the Court held that extracting a blood sample from an unconscious defendant did not constitute conduct of the character condemned in Rochin, although it was implied that a different result might have been reached had the defendant been conscious and resisted the attempt by police to secure the sample. ${ }^{23}$ The utility of this test was questioned, however, in a vigorous dissent on the ground that conduct which may shock the conscience of one man may be deemed reasonable by another. ${ }^{24}$

352 U.S. 432 (1957).

"2 Chief Justice Warren, in dissent, drew this implication from the following words of Mr. Justice Clark's majority opinion: "To be sure, the driver here was unconscious when the blood was taken, but the absence of conscious consent, without more, does not necessarily render the taking a violation of a constitutional right. . . " 352 U.S. 432,435 (1957).

"The majority of the Court pointed out that blood tests are quite common in modern medicine and are not an unusual occurrence in the life of the average citizen. Furthermore, they involve only slight discomfort and inconvenience, and a regulation of the State of New Mexico, wherein the Breithaupt case arose, prohibits state police officers from securing a blood sample unless the process of extraction is performed by a qualified physician. Even in the cases of municipal law enforcement, it is "the customary administrative practice" in New Mexico to allow blood to be withdrawn only by a doctor. The Court was assured by the representative of the state who argued the case that "in -no instance had a municipality or the state police permitted the test to be made without these precautions." 352 U.S. 432,438 , n. 5 (1957). Finally, the Court concluded that the slight intrusion necessary to secure the blood was a small price to pay in relation to the interest of the public in ridding the highways of drunken drivers.

Mr. Justice Clark, for the majority, stated: "The blood test procedure has become routine in our everyday life. It is a ritual for those going into the military service as well as those applying for marriage licenses. Many colleges require such tests before permittiug entrance and literally millious of us have voluntarily gone through the same, though a longer, routine in becoming blood donors. Likewise, we note that a majority of our States have either enacted statutes in some form authorizing tests of this nature or permit findings so obtained to be admitted in evidence. We therefore conclude that a blood test taken by a skilled technician is not such 'conduct that shocks the conscience,' [Citing Rochin v. California, 342 U.S. 165 (1952)] nor such a method of obtaining evidence that it offeuds a sense of justice." [Citing Brown v. Mississippi, 297 U.S. 278, 285-6 (1936).] 352 U.S. 432, 436-437 (1957).

The Chief Justice, on the other haud, pointing out the similarities between the fact situations in Rochin aud Breithaupt, first took issue with the majority for making physical resistance a "prerequisite to the existence of his (defendant's) constitutional rights," 352 U.S. 432, 441 (1957), and then stated that the only distinction between the cases was purely a matter of personal reaction; to fouud legal principles upon any such distinction "is to build on shifting sands." 352 U.S. 432, 442 (1957). Justices Black and Douglas joined in the dissent of the Chief Justice. 


\section{Decisions in the State Courts}

The same objections to the admissibility of evidence based on the forcible extraction of body fluids have been raised in state courts. ${ }^{25}$ Most frequently invoked has been the privilege against self-incrimination. ${ }^{20}$.Typically, however, in State v. Cram, ${ }^{27}$ it was held that evidence of intoxication obtained by taking a blood sample from an unconscious defendant did not violate this guarantee, since the evidence was obtained without the use of any process against him as a witness. ${ }^{28}$ And, evidence which is obtainable from a suspect without the possibility of a perjured confession through threatened or actual bodily injury, it is argued, is not logically subsumed within this privilege.

Several jurisdictions have, however, held inadmissible evidence based on physical data supplied by the defendant. ${ }^{29}$ But even here distinction

${ }^{95}$ For a collection of cases see Annot. I64 A.L.R. 967 (1946), supplemented by Annot. 25 A.L.R.2d 1407 (1952).

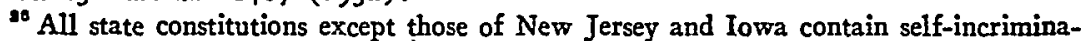
tion clauses. 8 WigmorE, EVIDENCE $\S 2252$ ( 3 rd ed. I940). See generally: Inbau, Should We Abolish the Constitutional Privilege A gainst Self-Incrimination, $45 \mathrm{~J}$. CrIM. L., C. \& P.S. 180 (1954); Moreland, Historical Background and Implication of the Privilege Against Self-Incrimination, 44 Kr. L.J. 267 (1956); Morgan, The Privilege Against Self-Incrimination, 34 MinN. L. REv. I (1949). See as well, Corwin, The Supreme Court's Construction of the Self-Incrimination Clause, 29 Mich. L. REV. I (1930).

${ }_{17} 176$ Ore. 577,160 P.2d 283 (1945).

28 ". . . the object of the protection seems plain. It is the employment of legal process to exract from the person's own lips an admission of his guilt, which will thus take the place of other evidence. Such was the process of the ecclesiastical Court, as opposed through two centuries-the inquisitorial method of putting the accused upon his oath, in order to supply the lack of the required two witnesses. Such was the complaint of Lilburn and his fellow-objectors, that he ought to be convicted by other evidence and not by his own forced confession upon oath....

"In other words, it is not any and every compulsion that is the kernel of the privilege in history and in the constitutional defnitions, but testimonial compulsion. The one idea is as essential as the other.

"The general principle, therefore, in regard to the form of the protected disclosure, may be said to be this: The privilege protects a person from any disclosure sought by legal processes against him as a witness." 8 WigMORE, EvideNCE' $\$ 226_{3}$ (3rd ed. i940).

. "Whenever the evidence is confined ... to qualities of his (defendant's) body "substances beyond his power of control, its admissibility is clearly justified by the more liberal interpretation of the Constitutional provision. Where, however, he is compelled to do acts which he can use as a means of conveying ideas, the reception of evidence of his conduct raises serious questions as to the extent to which practical considerations affecting efficient enforcement of the law under modern conditions may be safely permitted to limit the right of privacy and personal liberty.' Morgan, The Privilege Against Self-Incrimination, 34 MiNN. L. REv. I, 39 (1949). 
has been drawn between evidence whose collation requires active participation on the part of the accused and that which requires his mere passive acquiescence, ${ }^{30}$ the latter universally being held admissible, since the defendant is not forced actively to produce the evidence which may convict him. ${ }^{31}$ Thus, in Apodaca v. State, ${ }^{32}$ the court held that since the appellant was required to touch, his finger to his nose, to walk rapidly and slowly, and to turn around abruptly, evidence thereof should not have been admitted at his trial, since "demonstration by an act 'which tends to self-incrimination is as obnoxious to the immunity guaranteed by the Constitution as one by words." "133

Still another pattern may be discerned: the tendency to hold inadmissible all evidence secured by compulsion ${ }^{34}$ regardless of activity or passivity on the part of the accused. Exemplary is State v. Height, ${ }^{35}$ which held inadmissible the results of a physical examination, made at the instance of the prosecuting attorney over the objection of the de-

\footnotetext{
${ }^{\text {*o }}$ For example, an accused may. be required to stand up in court or place himself in full view of witnesses and the jury. [Citing, inter alia, People v. Gardner, 144 N.Y. 119, 38 N.E. 1003 (1894); People v. Clark, 18 Cal.2d 449, 116 P.2d 56 (1941); also State v. Clark, I 56 Wash. 543, 287 Pac. 18 (1930); State v. Vincent, 222 N.C. 543,23 S.E.2d 832 (1943).]

Similarly, exhibition of tattoos, scars, marks and wounds has been held admissible. [Citing, State v. Ah Chuey, 14 Nev. 79 (1879); State v. Garrett, 71 N. C. 85 (1874); State v. Coleman, 96 W.Va. 544, 123 S.E. 580 (1924).]

Likewise, comparison of footprints, removal of disguises and comparison of fingerprints and photographs have been held almost unanimously admissible. INBAU, SELFINCRIMINATION, passim (1950).

${ }^{21}$ This distinction is graphically illustrated by the Texas cases of Apodaca v. State, 140 Tex. Cr. R. 597, 146 S.W.2d 381 (1940) and Ash v. State, 139 Tex. Cr. R. 420, 141 S.W.2d 341 (1940), although it does not appear that the privilege was raised in the latter case. See also, State v. Griffin, 129 S.C. 200, 124 S.E. 81 (1924); State v. Barela, 23 N.M. 395, 168 Pac. 545 (1917). See Note, 44 KY. L.J. 353, 357 (1956), citing Allen v. State, 183 Md. 603, 39 A.2d 820 (1944) 3 Green Lake County v. Domes, 247 Wis. 90 , 18 N.W.2d 348 ( 1945 ).

${ }^{28} 146$ S.W.2d 381 (Tex. 1940).

${ }^{38} 146$ S.W.2d 381,382 (Tex. 1940).

st This interpretation would prohibit any evidence obtained by force from an accused, regardless of the degree of force used to compel its collation. Proscribed under this doctrine would be such evidence as fingerprints, photographs, urinalyses, physical examinations and "line ups." Wigmore criticizes this approach, pointing out that what is obtained from the accused is not testimony about his body, but the body itself. The emphasis is erroneously placed on compulsion rather than testimony. 8 WIGMORE, EviDENCE, $\$ 2265$ p. 375 (3rd ed. 1940). Apparently, this view expressed that no evidence obtained by compulsion is admissible, stems from a repugnance at admitting anything secured from one which may lead to his conviction.

${ }^{35}{ }_{17}$ lowa 650, 91 N.W. 935 (1902).
} 
fendant-examinee, to determine the presence or absence of venereal disease. ${ }^{36}$ However, this line of authority is now quite attenuated. ${ }^{37}$

State v. Height $t^{38}$ also illustrates a further objection to the forcible extraction of body fluids, the claim of unreasonable search and seizure, which has similarly met with little success, ${ }^{39}$ although there are deviant decisions. ${ }^{40}$ A judicial failure to distinguish between the act of unlawful search and seizure and the use of evidence so obtained, however, has often led to confusion in application of sanctions and remedies flowing

\footnotetext{
${ }^{30}$ The court rested its decision squarely upon the due process clause of the Iowa Constitution, stating that the examination was the result of the invasion of defendant's constitutional right, impliedly guaranteed under the provision of the constitution as to due process of law not to criminate himself.

Professor Wigmore criticizes the Height case on the grounds that "the attempt ... to read the privilege (self-incrimination) by implication into the clause of 'Due process of law' is futile and unhistorical; that clause is already a catch-all, overflowing with misplaced principles, and no 'ex post facto' interpretation can make room for it in the present privilege." 8 WIGMORE, EVIDENCE, $\S 2252$ n. 2 (3rd ed. 1940).

${ }^{37}$ See State v. Newcomb, 220 Mo. 54, 1 I 9 S.W. 405 (1909); 44 KY. L.J. 353 supra note 3r. Apparently, these are the only decisions which adopt this view, and their validity is somewhat in doubt.

ss Another objection was raised as well, the claim of doctor-patient privilege, which was rejected in accord with the prevailing rule. Wigmore states: "The confidence that is protected is only that which is given to a professional physician during a consultation with a view to curative treatment; for it is that relation only which the law desires to facilitate." 8 Wigmore, Evidence $\$ 2382$ p. 817 (3rd ed. 1940). See City and County of San Francisco v. Superior Court in and for City of San Francisco, 37 Calif. 227, 23 I P.2d 26 (195x).

The courts usually reason that the accused did not summon the physician, Leard $v$. State, 235 Pac. 243 (Okla. I925), or that the examination was not conducted with the idea of creating a physician-patient relationship, State v. Height, supre note 35, or that no medical treatment was given or contemplated; but where the doctor renders treatment to the accused in addition to taking the sample, there may be grounds for excluding his testimony. However, even when first aid is rendered, it is thought that the privilege should extend no further than to information necessary to render proper treatment, which would not include the taking of the blood sample. Ladd and Gibson, LegalMedical Aspects of Blood Tests to Determine Intoxication, 29 VA. L. REv. 749 (1943).

${ }^{30}$ "It has long been established that the admissibility of evidence is not affected by the illegality of the means through which the party has been enabled to obtain the evidence." 8 WIGMORE, EvIDENCE, $\S 2$ I83 p. 5 (3rd ed. 1940). However, a substantial minority of the states follow the federal exclusionary rule. MCCormick, EVIDENCE, $\S$ I 39 p. 295 (I954). A recent count indicates that this minority numbers twenty-one. Note, 5 UTAF L. REV. I 6 n. 6 (1956). Nevertheless, Wigmore states that "a warrantless search-and-seizure after or upon a lawful arrest is not within the exclusionary rule." 8 WIGMORE, EvideNCE, $\$ 2$ I 84 a p. 4I (3rd ed. 1940). See State v. Weltha, 228 Iowa 519,292 N.W. 148 (1940).

${ }^{10}$ Illustrative is United States v. Willis, 85 F. Supp. 745 (S.D. Cal. 1949). See Note, Use of Stomach Pump as Unreasonable Search and Seizure, 4I J. CRIM. L., C. \& P.S. (1950).
} 
from each under the doctrine of Wolf v. Colorado. ${ }^{41}$ Consequently, an attack on the forcible extraction of fluids from the body of an accused by state officers on the ground that it constituted an unreasonable search and seizure might, at least theoretically, prove successful; as a practical matter, however, the successful maintenance of this contention would not necessarily preclude the admission of the evidence thus unlawfully obtained, unless, perhaps, the particular state had adopted an exclusionary rule of its own as a matter of policy. ${ }^{42}$

The possibility of waiver of one or more of the privileges must also be considered. ${ }^{3}$ Certainly, a voluntary examination will bar the accused from later asserting a constitutional privilege with respect thereto." Furthermore, some courts have held the submission to be voluntary where the accused erroneously believed that the law required him to submit, ${ }^{45}$ or was ignorant of the reason for the examination, ${ }^{40}$ or was under the mistaken belief that the examination was for treatment, ${ }^{37}$ or simply failed to give active resistance. ${ }^{88}$ Moreover, other courts have placed the burden of proving. coercion on the accused, ${ }^{40}$ and two states have enacted statutes providing for "implied consent" to a blood test, whereby the accused waives his constitutional privileges by accepting the "privilege" of using the state highways."

To mitigate evidentiary diffculties in establishing intoxication, twenty-three states have enacted statutes providing for the use of chemical tests to determine the amount of alcohol present in the blood, urine, or breath of the accused. ${ }^{\text {si }}$ A few states have judicially accepted the use

1238 U.S. 25 (1949).

"See note 39 supra.

"s State v. Duguid, 50. Ariz. 276, 72 P.2d 435 (1937); State v. Cash, 219 N.C. 818, 15 S.E.2d 277 (1941). See 2 Wharton, Criminal Evidence, § 659, p. 561 (12th ed: 1955).

"Spitler v. State, 221 Ind. I0\%, 46 N.E.2d $59 x$ (1943).

"s State v. Werling, 234 Iowa 1 109, 13 N.W.2d 318 (1944).

"State v. Duguid, supra note 43 .

"Davis v. State, 189 Md. 640, 57 A.2d 289 (1948).

${ }^{48}$ Touchton v. State, 154 Fla. 682, 18 So.2d 752 (1944); Logan v. State, 269 P.2d 380 (Okla. 1954). Cf. State v. Horton, 247 Mo. 657, 153 S.W. 1051 (1913).

"See generally, Wharton, op. cit. supra note 43 .

${ }^{\text {so }}$ KAN. SESS. LAWS, 1955, c. 6I, p. 165; N.Y. Vehicle and Traffic LAW $\S 70(5)$ and $\S 712$ (1957 Supp.). See generally Mamet, Constitutionality of Compulsory Chemical Tests to Determine Alcoholic Intoxication, 36 J. CRIM. L., C. \& P.S. 133 (I 945).

${ }^{82}$ The following states have enacted such statutes: Arizona, Delaware, Georgia, Idaho, Indiana, Kansas, Kentucky, Maine, Minnesota, Nebraska, New Hampshire, New Jersey, New York, North Dakota, Oregon, South Carolina, South Dakota, Tennessee, Utah, 
of chemical tests for intoxication without legislative direction, ${ }^{52}$ but nine states expressly require the consent of the accused before such tests can be used.63 Only one state outlines in detail the procedure for the taking of the body fluids and the making of the tests.

\section{ConClusion}

Constitutional guarantees of individual rights are inherently limited by the demands of public welfare. But where is the balance to be struck? Chief Justice Warren, dissenting in Breithaupt v. Abram, attempted to provide such a standard:

We should, in my opinion, hold that due process means at least that law-enforcement officers in their efforts to obtain evidence from persons suspected of crime must stop short of bruising the

Virginia, Washington, Wisconsin, Wyoming. See Comment, Constitutionality of Chemical Tests for Drunken Drivers, i 8 ALBANY L. REv. 203 (1954).

${ }^{85}$ For example, in State v. Damm, 64 S.D. 309,266 N.W. 667 (1936), decided sixteen years prior to the enactment of the South Dakota statute, it was held “... that physical examination or the taking of a few drops of blood does not amount ... to an infringement of any constitutional right, for if it was such infringement, manifestly the Legislature would be powerless to decree it. It is our position that a statute can neither add to nor detract from the inherent power of the court in such a matter.... If it is not an invasion of constitutional rights (and we think it very clearly is not), then it lies within the ambit of the inherent judicial power of cqurts of record, and legslative permission or authority is superfluous." See also People v. Haeussler, 4 I Cal.2d 252, 260 P.2d 8 (1955); Block v. People, 125 Colo. 36, 240 P.2d 512 (1952); Touchton v. State, I 54 Fla. 682, 18 So.2d 752 (r944); People v. Bobezyk, 343 IIl. App. 504, 99 N.E.2d 567 (195x); State v. Haner, 23 x Iowa 348, x. N.W.2d 91 (1941); State v. Morkrid, 226 Iowa 1211, 286 N.W. 413 (1939); United States v. Nesmith, 121 F. Supp. 758 (D.D.C. 1954); Novak v. District of Columbia, 49 A.2d 88 (Munic. Ct. of App. D.C. 1946); Logan v. State, 269 P.2d 380 (Okla. 1954); McKay v. State, 55 Tex. Cr. R. 416, 235 S.W.2d 173 (1950). Cf. State v. Gatton, 60 Ohio App. 192, 20 N.E.2d 265 (1938).

${ }^{88}$ By statute, the following states require consent: GA. CODE ANN. § 68-1625 (Cum. Supp. 1955); KY. Rev. STAT. ANN. § 189.520 (1955); ME. Rev. STAt. ANN. c. 22, \$ 150 (1955 Supp.); Minn. Stat. \$ 169.12 (Cum. Supp. 1956); Neb. Rev. Stat. § 39-727.01-727.02 (1953); N.J. REv. STAT. \$ 39:4-50.I (Cum. Supp. 1955); N.D. Rev. Code $\S-(1953)$; ORE. Rev. Stat. $\$ 483.630$ (1955); VA. CODE ANN. $\$ \S$ I 8-75.1-75.3 (Supp. 1956).

"VA. CODE ANN. \$ 18-75.1 (Supp. 1956). "The blood sample shall be placed in a sealed container. . . . Upon completion of taking the sample, the container must be resealed in the presence of the accused after calling the fact to his attention. The container shall be especially equipped with a sealing device . . . labeled and identified showing the person making the test, the name of the accused, the date and time of the taking. ..."

${ }_{35} 35$ U.S. 432,442 (195.7). 
body, breaking the skin, puncturing tissue or extracting body fluids, whether they contemplate doing it by force or by stealth.

However, the interests of society in curbing the increasing highway death rate, due in no small part to drunken driving, ${ }^{56}$ coupled with minimal incidental pain and discomfort involved in the extraction of body fluids, demand some modification of the Chief Justice's suggestion that inviolability of the human body become an incident of due process where it is suspected that an accused is under the influence of alcohol or narcotics. ${ }^{57}$ Thus, evidence obtained as the result of body fluid analyses should be rendered admissible only where the following criteria co-exist:

(I) an overriding public necessity demanding at least minimal invasion of individual rights;

(2) a taking which entails no more than a nominal degree of pain or discomfort, or which entails more than a nominal degree of pain or discomfort lasting not more than a few seconds, and

(3) a taking which entails no more than a negligible possibilty of infection, disease, or lasting ill effects.

Thus, standards are adduced whereby the courts may, upon the merits of each case, afford maximum protection to the rights of the individual $^{58}$ consistent with the public weal.

${ }^{80}$ In $1955,7 \%$ of the fatal accidents involving automobiles in urban areas were due to drunken driving. This is closely paralleled by the $8 \%$ figure in rural arcas. According to reports from twenty states, drinking on the part of a driver or pedestrian was reported in twenty-six out of every 100 fatal accidents. The figures on drinking drivers ranged from seven out of every 100, to forty-five out of every 100. Six out of every 100 drivers involved in fatal accidents were classified as drunken drivers or "under the influence of alcohol." Applying these figures to the 1955 motor death toll of 38,300 in all forty-eight states, roughly 2,300 persons lost their lives that year as a result of drunken driving. National SAFETY Council, Accident Facts, 51, 53 (1956).

${ }_{82}$ The Model Code of Evidence of the American Law Institute takes the following position when the self-incrimination privilege has been raised: "No person had a privilege . . . to refuse. ... (b) to furnish or to perınit the taking of samples of body fluids or substance for analysis." MODEL CODE OF EvIDENCE rule 205 (1942). This rule, however, would apparently not preclude any other constitutional objection.

sa This analysis does not comprehend recourse for an injury sustained as the result of a forcible taking of hody fluid samples, the ostensible remedy for which is an action of battery against the officers involved. While this remedy is of dubious practicality, curative measures inust stem from the pressure of public opinion directly or from legislation. 